\title{
Independence of criminal judges in Kenya - current issues
}

\author{
By Nabil M. Orina*
}

\section{INTRODUCTION}

Over a long time, the Kenyan judiciary suffered a confidence crisis in the eyes of the public. ${ }^{1}$ It was largely seen as controlled by the executive as well as bedeviled by massive corruption $^{2}$. These perceptions formed the basis for the almost radical transformations introduced by the Constitution of Kenya 2010 (the Constitution) which required vetting of all the magistrates and judges in office at the time of promulgation of the constitution. ${ }^{3}$ The Constitution further introduced other mechanisms that aimed to bolster the public confidence in the judiciary ${ }^{4}$. Has the goal of an independent judiciary been achieved and has the public confidence been restored? This paper contributes to that debate by addressing the subject of the independence of criminal judges (and magistrates) in Kenya.

To do that, the first part addresses the general subject of independence of the judiciary in Kenya by laying out the key provisions in the law, the second part focuses on appointment and remuneration of judges and magistrates in Kenya, the third part discusses the assignment of judges to various divisions and the transfer policy and the last part concludes by highlighting the current issues.

\section{A. INDEPENDENCE OF THE JUDICIARY IN KENYA}

Whereas the Bangalore Principles of Judicial Conduct can be viewed and termed as being the blueprint for judicial code of ethics and conduct the world over ${ }^{5}$, states have taken steps

* Advocate of the High Court of Kenya, Public Law Lecturer - Moi University, Email: orina_mokaya@yahoo.com.

This lecture was delivered at the $4^{\text {th }}$ Regional Conference on "Requirements for an independent and effective judiciary in Burundi, DR Congo, Kenya, Rwanda, Tanzania and Uganda - current problems in criminal and civil proceedings" held in Nairobi on $2^{\text {nd }}-3^{\text {rd }}$ September 2016.

1 The Judiciary Transformation Framework, 2012-2016, http://www.judiciary.go.ke/portal/page/judic iary-transformation-framework (last accessed on 2/09/2016); International Commission of Jurists, 'Reflecting, Monitoring and Embedding, Integrity Concepts within the Judicial Reform and the Constitutional Reform Process', ICJ Kenya and KAS Annual Jurists conference (2010) 5.

2 Mr. Justice (Rtd) Aaron Ringera, 'Corruption in the Judiciary' (World Bank, Washington D.C, 25 April 2007) 11..

3 Prof. PLO Lumumba, 'Judicial Innovation or Schizophrenia?: A Survey Of Emerging Kenyan Jurisprudence', Law society of Kenya annual conference (Kenya Law 2014).

4 Farnoosh Hashemian, 'A New Constitution and the Agenda for Judicial Reform', IDEA-IDLO Workshop on the Role of Judiciary in Constitutional Transitions (2014) 2.

5 'Commentary on the Bangalore Principles of Judicial Conduct' (United Nations Office on Drugs and Crime 2007) 13. 
of translating the same into the national codes ${ }^{6}$. These principles comprising of six core values being independence, impartiality, integrity, propriety, equality and competence and diligence have been reflected in the Constitution of Kenya, 2010 as well as by the Judicial Code of Conduct (hereinafter the code). The code came into operation in June after the Chief Justice and the Judicial Service Commission made the rules in compliance with section 47 of the Judicial Service Act as read with section 39 of the High Court (Organisation and Administration) Act 2015 and section 21 of the Magistrates Courts Act. 2015. ${ }^{7}$ Effectively, the code revoked the Judicial Service Code of Conduct and Ethics issued under section 5 of the Public Officer Ethics Act, 2003. ${ }^{8}$

The Code is meant to give effect to Art 168(1)(b) and 172 (1)(c) of the Constitution ${ }^{9}$, the Bangalore Principles of Judicial Conduct and to supplement and not derogate from the General Leadership and Integrity Code for State officers as prescribed under the Leadership and Integrity Act, No. 19 of 2012, and any other law and conduct which is intended to bind judges and judicial officers. ${ }^{10}$

The code has provisions specifically meant to apply to judges only under Part II. This particular part of the code is modeled to conform to the Bangalore principles with emphasis being placed in eight key principles to be observed by judges in the dispensation of their duties.

The code requires judges to exercise judicial authority independently based on their assessment of facts and in accordance with a conscientious understanding of the law, free of any extraneous influences, inducements, pressures, threats or interference, direct or indirect, from any quarter or for any reason.

The code also requires judges to encourage and uphold safeguards for the discharge of judicial duties in order to maintain and enhance the institutional and operational independence of the judiciary. In doing this, a judge(s) shall exhibit and promote high standards of judicial conduct in order to enhance public confidence in the judiciary, which is fundamental to the maintenance of judicial independence.

\section{B. APPOINTMENT OF JUDGES AND MAGISTRATES IN KENYA}

The qualifications for appointment of Judges are set out in the constitution ${ }^{11}$. Those for the appointment as magistrates are provided for under section 32 of the Judicial Service Act.

6 'Measures for the Effective Implementation of the Bangalore Principles of Judicial Conduct' (Report adopted by Judicial Integrity Group in Lusaka, Zambia 2010).

7 Judicial Code of Conduct, Preamble.

8 Public Officer Ethics Act Legal Notice No. 50 of 2003.

9 Grounds for removal of a judge from office.

10 Judicial Code of Conduct, S3.

11 Constitution of Kenya 201, Art. 166. 
Independence and accountability of the judiciary (as a structure) is ensured through the appointment process undertaken by the Judicial Service Commission (JSC) rather than the executive. $^{12}$

The procedure commences with JSC advertising for the vacant position(s) and calling for expression of interest ${ }^{13}$. Thereafter, it constitutes a selection panel which consists of at least five members whose function is to shortlist persons for nomination by the commission. ${ }^{14}$

The members of the panel elect a chairperson among themselves. They forward the names of the successful applicant(s) for the position of judge to the president for appointment. The president then forwards their names to the National assembly for approval. However, the appointees for magistracy do not require presidential/National Assembly approval.

\section{ESTABLISHMENT OF DIVISIONS OF THE HIGH COURT AND ASSIGNMENT OF JUDGES}

As part of his administrative duties, the Chief Justice has powers to establish various divisions of the High Court "for purposes of promoting effectiveness and efficiency in the administration of justice. ${ }^{15}$ The existing divisions of the High Court are: the Family and Children Division, Commercial Division, Admiralty Division, Civil Division, Criminal Division, Constitutional and Human Rights Division and Judicial Review Division. ${ }^{16}$

Whereas the establishment of new divisions of the High Court in addition to the existing ones has been left to the Chief Justice in consultation with the Principal Judge of the High Court, ${ }^{17}$ the question of assignment of judges to the established divisions is not spelt out in the law giving leeway to the Chief Justice to assign judges to these divisions without a known criteria. In effect, the law only provides for minimum qualifications for being a judge of the High Court and does not specify any special qualifications to sit in any of these divisions other that the Environmental and Land Court (ELC) ${ }^{18}$ and the Employment and Labour Relations Court (ELRC) ${ }^{19}$ which are courts of the same status as the High Court but regulated by separate laws.

12 Julie Ouma Oseko, 'Judicial Independence in Kenya: Constitutional Challenges and Opportunities for Reform' (Thesis submitted for the degree of Doctor of Philosophy at the University of Leicester, 2011).

13 Judicial Service Act, S9.

14 Ibid, S30.

15 Section 11 (1) (a-g), High Court (Organisation and Administration) Act.

16 Ibid.

17 Ibid, Section 11 (1) (h.).

18 Established under Section 162 (2) (a) of the Constitution of Kenya, 2010.

19 Established under Section 162 (2) (b) of the Constitution of Kenya, 2010. 
A question has come before court on whether an ELC judge could sit in another division of the High Court and vice versa. ${ }^{20}$ In Kenya Medical Research Institute v the Attorney General, ${ }^{21}$ the Chief Justice had empanelled a bench of three judges under Article 165(4) of the Constitution, two from the High court and one from the ELRC, to hear a constitutional petition filed in the ELRC. An interested party to the petition raise an objection to the bench as empanelled with arguments that the mixed bench was itself unconstitutional and could not hear the constitutional petition. The Court unanimously dismissed the objection and held that in assigning Judges under Article 165(4) of the Constitution the Chief Justice is free to appoint any judge of the High Court or a Judge of the Court with the status of the High Court.

The Court of Appeal deliberated on the issue in Jefferson Kalama Kengha \& 2 others $v$ Republic. ${ }^{22}$ In that case, the appellants sought to overturn their convictions, which the High Court had upheld, on the basis inter alia that an ELC Judge who had heard and determined the appeals, in a bench wherein also sat a High Court Judge, had no jurisdiction to preside over the appeals. The Court held that much as the Chief Justice acted in good faith and intention in assigning the judges of ELRC and ELC to hear and determine criminal appeals, he nonetheless violated the Constitution as he had no power to confer jurisdiction except where the law specifically provides and such power must be exercised within the confines of such law.

The Court in Jefferson Kalama Kengha further deliberated on the issue of Judicial Independence and stated the ELRC and ELC under Article 162(2) were intended to be autonomous, distinct and independent of the High Court and it is for that reason that it was bestowed with the status of the High Court. The court was of the view that it was the intention of the drafters to give ELRC and ELC independence from the High Court. This independence is essential to the role of the Courts as specialized courts charged with the responsibility of developing coherent and evolving labour relations, environment and land jurisdiction. ${ }^{23}$ Consequently, shuffling the Judges appointed to these courts to other courts may subvert this aim. Shouldn't this be the case in other divisions especially the Criminal Division which may require development of sound criminal jurisprudence in advancement of the rights granted in the Constitution of Kenya 2010?

20 Samson Matende v Republic, Criminal Appeal No. 141 of 2009; Kenya Medical Research Institute $v$ The Attorney \& 3 others (2014) eKLR; Benson Ndiwga Njue \& 80 others v Central Glass Ltd, HCCC NO. 505 of 2003.

21 (2014) eKLR.

22 (2015) eKLR.

23 Constitution of Kenya, Art. 162(2); Environment and Land Court Act Cap 12A, S13; Environment and Labour Relations Court Act Cap 234B, S12. 


\section{TRANSFER OF JUDGES WITHIN DIVISIONS AND STATIONS AND CURRENT ISSUES}

In deciding where to post a judicial officer, the judiciary is primarily guided by the need to serve justice with expediency, which is appointment to stations that need their services most given the amount of nature of work in the stations. ${ }^{24}$

The objective of the transfer policy is to provide for smooth predictable and equitable rotation of judicial officers to minimize undue disruption to the administration of justice and to lives of judicial officers. ${ }^{25}$

The transfer decisions are made by the Chief Justice but can delegate the implementation of policy to the registrar responsible for magistrate's courts and the principal judge of high court. ${ }^{26}$

A judicial officer who has served for more than three years in a station shall be eligible for a transfer and this shall be effected by the 30th of September every year and shall be required to report at the new stations in January the following year but in special transfers reporting dates shall be indicated in the transfer letter issued by Chief Justice. ${ }^{27}$

Abrupt transfer of judicial officers creates havoc in the stations where the judicial officers operate from. On February 2015, immediate and abrupt transfer of 31 top magistrates was reported. ${ }^{28}$ The transfer created unwarranted confusion since at least about one thousand 'part heard' cases was placed in jeopardy and delays of months, and even years. ${ }^{29}$ During such transfers, most case would start de novo which will be costly and timely and unreasonably delaying cases below the ultimate standard of justice.

\section{E. CURRENT ISSUES/ CONCLUSION}

\section{I) Bail/Bond}

Under Article 49(1) of the constitution an arrested person has the right "to be released on bond or bail, on reasonable conditions, pending a charge or trial, unless there are compelling reasons not to be released."

Despite the enactment of the Bail and Bond Regulations, 2015, an issue arises in almost all bail hearings, to wit; what amounts to compelling reasons? It is especially so in cases

24 Transfer Policy \& Guidelines for Judicial Officers, Preamble.

25 Ibid.

26 Ibid, Part II.

27 Ibid, Part III.

28 Abrupt Transfer of Magistrate Questionable, http://www.standardmedia.co.ke/article/2000151309/ abrupt-transfer-of-magistrates-questionable (last accessed on 02/09/2016).

29 Ibid. 
connected with terrorism ${ }^{30}$. As Elisha Ongoya ${ }^{31}$ notes, the executive's position has been that suspects to such offences should not be granted bail. Such proposals have been made to the judiciary through 'roadside declarations'.

In my view, these proposals by the state and other forms of pressure from the public amount to interference of the independence of judges since it makes them consider factors outside the law and the facts in the respective cases. A case in point is Hassan Mahat Omar \& another Vs Republic ${ }^{32}$ wherein the suspects were denied bail because the nature of the charges against them was 'serious'.

To deal with this issue, it is important to create awareness (especially to criminal court judges) on the operation of the right to bail and the content of bail/bond Regulations. Scholars have also suggested the need to establish a bail court, separate from the actual criminal trial court so as to enable examination of all material that the prosecution might have against the accused person hence preventing prejudice arising from interference by stated actors $^{33}$.

\section{II) Corruption/Economic Crimes Cases}

The challenge in most economic cases is that the suspects involved are usually very powerful or having close ties with the state. That leads to the possibility of bribery (compromise) which makes prosecution of such cases hard.

To handle these cases in an expedient and fair manner, it would be imperative to invest in capacity building. Similarly, the judicial arm (in general) would need to embrace interdependence in terms of policy, with other arms of government.

\section{III) Inconsistent and Incoherent Jurisprudence}

The biggest issues emanating from lack of a permanent criminal division of the High Court is lack of consistence on certain issues especially determination of bail/bond, remedies for breach of fair trial rights and general principles of criminal law. The existing jurisprudence is inconsistent pointing to a likely influence of outside factors which could be the politics of the day as well as public pressure. A more permanent division would ensure promotion of independence in the operations of the division and development of a Kenyan criminal jurisprudence.

30 The definition of terrorism is broad and controversial.

31 Kenya Law, 'Legal And Policy Dilemma In The Fight Against Terrorism: The Bail Question In Terrorism Cases In Kenya'.

32 Nairobi High Court Criminal Revision No. 31 of 2013.

33 Supra, note 33. 


\section{REFERENCES}

1. The Judiciary Transformation Framework, 2012-2016. Retrieved September 2, 2016 from The Judiciary of Kenya website: http://www.judiciary.go.ke/portal/page/judiciary -transformation-framework.

2. International Commission of Jurists. (2010, December 3). Reflecting, Monitoring and Embedding, Integrity Concepts within the Judicial Reform and the Constitutional Reform Process. ICJ Kenya and KAS Annual Jurists conference (2010). Retrieved September 2, 2016 from http://www.kas.de/wf/doc/kas_21680-1522-2-30.pdf?110209060 945.

3. Mr. Justice (Rtd) Aaron Ringera. (2007 April, 25). Corruption in the Judiciary. Retrieved September 2, 2016 from http://eacc.go.ke/archives/Speeches/Justice_Ringera_Pres entation200407.pdf

4. Prof. PLO Lumumba. (August 25, 2014). Judicial Innovation or Schizophrenia?: A Survey Of Emerging Kenyan Jurisprudence. Retrieved September 2, 2016 from Kenya Law website: http://kenyalaw.org/kenyalawblog/judicial-innovation-or-schizophrenia/.

5. Farnoosh Hashemian,(August 2014). A New Constitution and the Agenda for Judicial Reform. Retrieved September 2, 2016 from http://www.constitutionnet.org/files/hashe mian.analysis_of_jmvb.idea_.final_.pdf.

6. United Nations Office on Drugs and Crime. (September 2007). Commentary on the Bangalore Principles of Judicial Conduct. Retrieved September 2, 2016 from https://w ww.unodc.org/documents/corruption/publications_unodc_commentary-e.pdf.

7. Judicial Integrity Group. (January 22, 2010). Measures for the Effective Implementation of the Bangalore Principles of Judicial Conduct. Retrieved September 2, 2016 from http://www.yargitay.gov.tr/sayfa/uluslararasi-belgeler/documents/bangaloreetigi. pdf.

8. Julie Ouma Oseko. (November, 2011). Judicial Independence in Kenya: Constitutional Challenges and Opportunities for Reform. Retrieved September 2, 2016 from https://lr a.le.ac.uk/bitstream/2381/27703/1/2012OsekojoPhd.pdf.

9. Elisha Zebedee Ongoyaa. (August 25, 2014). Legal and Policy Dilemma in the Fight Against Terrorism: The Bail Question in Terrorism Cases in Kenya. Retrieved September 2, 2016 from Kenya Law website: http://kenyalaw.org/kenyalawblog/legal-and-pol icy-dilemma-bail-question-in-terrorism-cases/.

10. Pravin Bowry. (February 11, 2015). Abrupt Transfer of Magistrates Questionable. Retrieved September 2, 2016 from standard digital website: http:/www.standardmedia.co .ke/article/2000151309/abrupt-transfer-of-magistrates-questionable

11. The Constitution of Kenya, 2010.

12. Judicial Code of Conduct.

13. Environment and Land Court Act Cap 12A.

14. Environment and Labour Relations Court Act Cap 234B.

15. Transfer Policy \& Guidelines for Judicial Officers. 
16. High Court (Organisation and Administration) Act.

17. Judicial Service Act, No.1 of 2011.

18. Public Officer Ethics Act Legal Notice No. 50 of 2003. 